\title{
The Fall of the Moche: A Critique of Claims for South America's First State
}

\section{Citation}

Quilter, Jeffrey, and Michele Koons. 2012. "The Fall of the Moche: A Critique of Claims for South America's First State." Latin Amer Antiquity 23 (2) (June 1): 127-143. doi:10.7183/1045-6635.23.2.127.

\section{Published Version}

doi:10.7183/1045-6635.23.2.127

\section{Permanent link}

http://nrs.harvard.edu/urn-3:HUL.InstRepos:34607120

\section{Terms of Use}

This article was downloaded from Harvard University's DASH repository, and is made available under the terms and conditions applicable to Other Posted Material, as set forth at http:// nrs.harvard.edu/urn-3:HUL.InstRepos:dash.current.terms-of-use\#LAA

\section{Share Your Story}

The Harvard community has made this article openly available.

Please share how this access benefits you. Submit a story.

\section{Accessibility}




\title{
THE FALL OF THE MOCHE: A CRITIQUE OF CLAIMS FOR SOUTH AMERICA'S FIRST STATE
}

\author{
Jeffrey Quilter and Michele L. Koons
}

\begin{abstract}
The Moche archaeological culture of the North Coast of Peru has been reified into a political system and claimed as the first state in South America. While some recent scholarship has reduced the size of the proposed state, the idea of Moche as a distinct political, social, or ethnic entity remains. In this article we demonstrate that even by the "classic" neoevolutionary theory of the 1960s-1980s the criteria for Moche statehood were not met. We suggest that neoevolutionary models for one or more Moche states are inadequate for understanding an archaeological culture that endured for more than six centuries, and we offer suggestions for directions for future research.
\end{abstract}

La cultura arqueológica Moche, de la costa norte del Perú, ha sido concebida como un sistema político y declarada el primer estado en Sudamérica. Aún cuando recientes investigaciones han reducido el tamaño del supuesto estado moche, la conceptualización de los moche como una entidad política, social y étnica distinguible aún subsiste. En este artículo demostramos cómo, aún bajo los estándares "clásicos" del neoevolucionismo de las décadas del los años 1960s a los 1980s, nunca se cumplieron los criterios para considerar a los moche como un estado. Sugerimos que los modelos neoevolucionistas son inadecuados para definir a los moche como uno o varios estados y para entender una cultura arqueológica que se extendió por más de 600 años. Finalmente, ofrecemos sugerencias para futuras investigaciones.

$\mathrm{T}$ The archaeological culture known as Moche or Mochica (ca.A.D. 350-900) of the North Coast of Peru (Figure 1) is frequently cited as the first, or one of the first, state societies in South America or the New World. Such claims are made both in specialist literature on the Central Andes and in synthetic, secondary publications summarizing the origins of the state, complex societies, and civilizations from a hemispheric or global perspective (Billman 2002, 2010; Haas 1982, 1987; Millaire 2009, 2010a; Stanish 2001). Interpretations of the specifics of Moche political organization vary to a considerable degree (see Quilter and Castillo 2010), but the model of a single, unitary, expansionist, multi-valley state, as developed in the 1970s and 1980s, is still maintained by many scholars (Bourget cited in Atwood 2010) and is commonly cited in generalist studies (e.g., Fagan 2008:341). Indeed, a depiction of a Moche lord graces the cover of a book on the origins of states (Maisels 2010).

Our purpose in writing this article is to critique neoevolutionary models and concepts of Moche as a state. Moche is an archaeological culture, a construct made by archaeologists that has been reified and shaped to conform to generalized models of statehood. We argue that neoevolutionary theory was and is inadequate to comprehend the social realities that lay beyond the construct of "Moche," and, indeed, that available data, even in the 1970s and 1980s when the model reigned supreme, did not fulfill the neoevolutionary criteria for statehood. The concept of a "normative" Moche statea bureaucratic governmental system-was developed and then data were found to support the concept. We suggest that identifying the ways in which political power was mobilized and employed is the key to understanding "Moche," and such a

Jeffrey Quilter Peabody Museum of Archaeology \& Ethnology, Harvard University, 11 Divinity Ave., Cambridge, MA 02138 (quilter@fas.harvard.edu)

Michele L. Koons « Department of Anthropology, Harvard University, 11 Divinity Ave., Cambridge, MA 02138 (mkoons@fas.harvard.edu) 


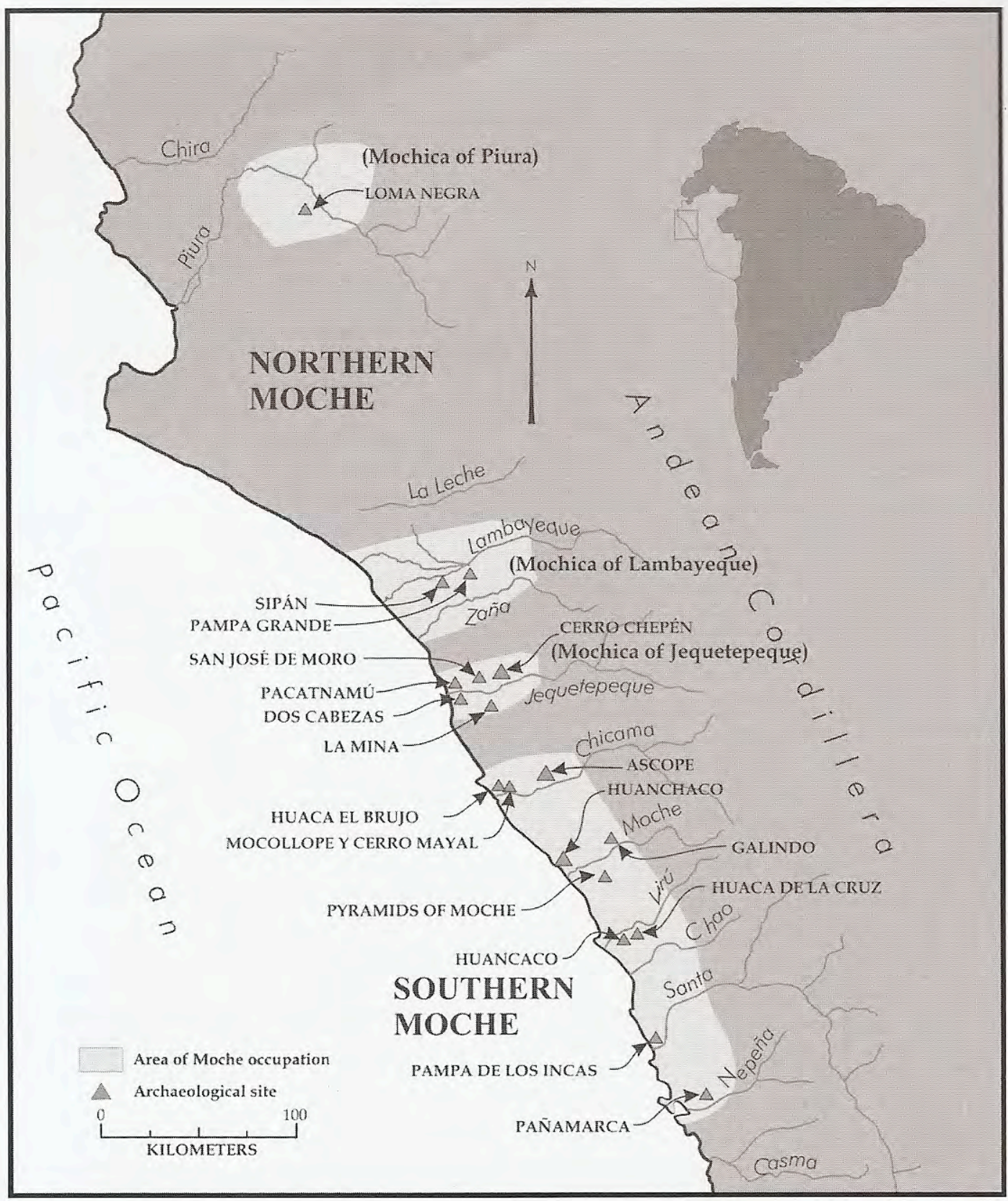

Figure 1. Map of Moche regions as currently conceived and significant Moche sites. Map courtesy of the San José de Moro Archaeological Program.

concern is not adequately addressed by neoevolutionary approaches that spend more time assessing whether a sufficient number of traits meet the criteria for statehood than understanding how politics and economics were carried out. We support the cross-cultural comparison of societies, past and present, as a fundamental task of anthropological archaeology, but we suggest that in order to do this well we need to rethink what Moche was.

In the following sections, we begin by presenting a review of how the concept of the state developed within the specific context of North Coast archaeology. This, perforce, requires a discussion of past research projects and the literature they gen- 
erated because that is how the argument was developed. We then review how data were interpreted to fit the preconceived model of Moche statehood as research progressed. We conclude our presentation by reviewing the theoretical problems in the neoevolutionary model and offer suggestions for new ways to conceive of Moche in future research.

\section{Conceptualizing the Moche}

The Moche and Chicama Valleys have long been thought of as the "core" Moche region (Castillo and Quilter 2010), but it is the presence of Moche artifacts and architecture in the other seven valleys, to the north and south of the heartland, that has been used as evidence of the expansion of the state. The most notable Moche artifacts are fine-ware ceramics with distinctive forms and decorations, such as stirrup spout bottles and floreros (flower pot shaped vessels) as well as metal objects-gold-copper alloy jewelry and regalia - and other material culture executed in generally similar styles. It has been the distinctive Moche art style in which these objects were rendered that identifies them as Moche or not. In addition, large adobe pyramids, locally known as huacas, were built millennia before Moche, but as key structures in ceremonial centers, they are considered essential aspects of Moche material culture.

In 1899 and 1900, Max Uhle (1913, 1915; Rowe 1954:7) was the first archaeologist to excavate a Moche site, Huaca de la Luna, at the architectural complex now known as the Huacas de Moche (Pyramids of Moche) in the Moche Valley from whence the site and culture derive their names. In the next generation, Rafael Larco Hoyle (1938, 1939), the hacendado of a large sugar plantation in the Chicama Valley, developed the first interpretation of Moche culture. He began with amateur investigations and soon developed an expertise rivaled by none, and it was he who coined the term "Mochica," to distinguish light colored, earlier ceramics from dark, later Chimú ones.

Larco wrote and published extensively about the Moche, ranking them high on the list of "advanced" societies as a civilization in the classic, evolutionary, sense of the term.

The ruins of urban and rural constructions, the agricultural expansion, the great irrigation works, monumental architecture and road sys- tems, all speak eloquently of a way of life organized through developed and matured governmental methods. Furthermore, the existence of exquisite artworks confirms that rulers were not only central in the creation of large scale facilities and public works but that they also influenced the diffusion of high culture ... (S)everely punishing all transgressions, the dynastic, theocratic and omnipotent Mochica government, forged through a robust and well oriented faith, this civilization, today, is the pride of our prehistoric past [Larco 1945:21-23; translation by Quilter].

The above quote exemplifies Larco's view of Moche as a great civilization comparable to the better-known, especially in the 1940 s, cultures of the ancient Old and New Worlds. He was consciously creating a national narrative to be embraced with pride. He viewed the Moche as a kingdom with a supreme ruler presiding over lesser lords, partly based on his identification of distinct personages depicted in "portrait head" vessels and, inferentially, because he assumed that a great civilization naturally was organized in a pyramid of power with a ruler at the top and a base filled with lower classes.

Larco constructed a five-phase ceramic chronology that he interpreted as uniformly distributed throughout the North Coast. Moche state expansion was inferred as having moved outwards from the Moche-Chicama heartland by the appearance of Moche ceramics in other valleys. The particular phase of Moche pottery first appearing in such a valley would mark the relative time period when the Moche conquest occurred.

While Larco was the father of Moche studies, the most significant event that shaped the course of Moche research for over three decades was the Virú Valley Project. Project directors William Duncan Strong and Wendell Bennett selected the Virú Valley for study, because it was "a small but important component of one of the oldest and most complex native civilizations in the Americas" (Strong and Evans 1952:3). At the time the work took place, in 1946, Moche was well known in Moche-Chicama mostly thanks to Larco's efforts. Thus, when stratigraphic excavations and other research in Virú showed a prior ceramic style, known as Gallinazo (and in Virú as "Virú"), abruptly ending and then succeeded by a "full- blown or even decadent stage" (Strong and Evans 1952:216) of Moche 
("Huancaco" in the Virú sequence), the interpretation that this intrusion was by conquest was easy to make, especially given the frequent depiction of warriors on ceramics and the many fortified sites identified in surveys (Willey 1953:358-360).

This view of Moche conquest was maintained even though it was recognized that there were "slightly pre-Huancaco aspect incursions of Mochica into the valley" (Strong and Evans 1952:217). The use of the term "incursions" suggests infiltration of belligerent forces conforming to the Virú Valley archaeologists' view of conquest as the best way to explain the changes they discerned in the archaeological record. Similarly, Collier (1955) took conquest as a given in his ceramics study, and Gordon Willey (1953:397) also assumed that Moche was a conquest state.

The collective and individual experiences of the Second World War surely had great influences on the interpretive perspectives of the Virú Valley Project members. The entire enterprise was part of a larger war/post-war effort with the U.S. State Department providing the funding (Willey 1988:117). ${ }^{1}$ In short, we suggest that the impact of war on the lives of archaeologists at the time of the Virú Valley project strongly influenced their interpretation of the Moche.

The Chan Chan-Moche Valley Project (CCMVP) of 1969-1974 was the next large-scale research project in the Central Andes. CCMVP research was based on the assumption of Moche as an expansive state, drawing directly from the Virú Valley research and Larco's views. While the greatest attention was devoted to the Chimú era Chan Chan complex, extensive work also was carried out at the Huacas de Moche, referred to as the Cerro Blanco site by the CCMVP (Moseley and Day 1982).

Michael Moseley's later (1992:166-184) coverage of the Moche in his survey of Andean archaeology best demonstrates those features that were interpreted as signatures of statehood. The antecedent Gallinazo culture was seen as a complex pre-state phenomenon with a distinctive ceramic style, large canals, and varied, hierarchically organized settlements, including large residential complexes and ceremonial centers in the Virú and Santa Valleys. From this, the "more centralized and consolidated rule arose" (Moseley 1992:166) when the Moche Valley polity was linked to Chicama.
Just as the generation of the Virú Valley Project members had been affected by World War II, the fact that the United States was engaged in the Vietnam conflict at the same time as the CCMVP likely played a significant role in shaping project members' conceptions of Moche as a conquest state. Larco, the Virú Project members, and the CCMVP researchers all conceived of the state as consisting of a governmental organ distinct from, though closely associated with, a state religion. There was no formal presentation of what the behavioral or organizational traits of a state are and the corresponding archaeological signatures of such traits. Rather, various archaeological data were identified as fulfilling criteria that were unspecified because, we assert, it was assumed that these were well known.

Moche, then, was an expansionist state that established a "Pax Moche" (Moseley 1992:183). The capital at Huacas de Moche consisted of the Huaca de la Luna, for the worship of the "national pantheon" (Moseley 1992:178) as in evidence by colorful murals and clean, and therefore sacred, spaces. On the other side of the Moche city, the largest adobe structure in the New World, the Huaca del Sol, was where heads of state reigned and were buried, although little research was conducted there and no high-status burials were found.

The centralized management of corporate labor was cited as in evidence by noting the segmental construction techniques of huacas and the use of marked adobe bricks (Moseley 1992:168), suggesting that sections of huacas were built by separate work gangs who identified their adobes by making distinctive marks in the bricks while they were still soft. "Corporate land management" (Moseley 1992:178) also was claimed, based on relict agricultural fields "laid out in a standardized manner ... divided into small rectangular plots of uniform size ... with small adobe platforms ... for supervisory personnel directing agricultural tasks" (Moseley 1992:178). Both huaca construction and work in the fields were interpreted as taxes that a peasantry rendered to the government.

Moseley (1992:179) also saw the Moche art style as an expression of strong, centralized control, and referred to it as a "corporate style." Although the term was never defined, the key to the concept seems to be standardization of forms (vessel shapes and decorations, huaca architecture) 
that "expressed corporate charters which defined political positions, official posts, and important vocations" (Moseley 1992:181).

The interpretation of the Moche conquest state saw its spread from its heartland in the Moche and Chicama valleys as a highly organized kingdom ruled by a hierarchical political organ with its priestly class in charge of the state cult. Donald Proulx (1985:275) summarized the three lines of evidence for the expansion of the Moche state as consisting of the sudden appearance of Moche pottery in conquered valleys, warriors and battle scenes in iconography, and the appearance of monumental-style Moche architecture in the conquered regions.

Thus, the CCMVP did not question or modify the Larco-Virú Valley Project model but reinforced it. Burials in the plain between the Huacas de Moche excavated by Christopher Donnan and Carol Mackey (1978) and some work in the urban sector and cleaning a profile at the Huaca del Sol (Pozorski and Pozorski 2003) were undertaken. Otherwise, very little excavation of Moche sites occurred during the fieldwork as the focus was on Chimú Chan Chan. Both before and after the CCMVP, most of the research in the southern valleys was in the form of surveys that, like the other investigations, were initiated and carried out with the assumption that Moche had been an expansive state, and this view held throughout the rest of the 1970 s through the 1980s and into the 1990s.

It needs to be emphasized that research on Moche topics was not the main effort of the CCMVP. Moche scholarship throughout much of the 1970 s through the 1980 s was mostly based on iconography (Bankes 1980; Benson 1972; Berezkin 1980, 1987, 1990; Castillo 1989; Donnan 1976,1978; Golte 1994; Hocquenghem 1987; Quilter 1990,1997). Questions concerning political organization largely went unaddressed because a general consensus on statehood had been reached and because the interests of researchers were largely on Moche religion and ritual. The ceramic collections on which they worked were mostly unprovenienced or poorly documented and the assumption of a uniform Moche religion (and state) were convenient tropes by which to examine what was assumed to be a uniform Moche iconographic corpus. To think otherwise would have challenged scholars wish- ing to make broad statements about Moche religious beliefs and practices.

After CCMVP, excavation projects on Moche sites were few with the exception of research at Pampa Grande in the Lambayeque Valley (Haas 1985; Shimada 1994), and Pacatnamú in the Jequetepeque Valley (Donnan and Cock 1986, 1997; Hecker and Hecker 1985; Ubbelohde-Doering 1983). After the results of excavations of the spectacular Sipán tombs started to be disseminated in 1987 (Alva 1988, 1994, 1999; Alva and Donnan 1993), however, a new research phase began with long-term field projects at the Huaca de la Luna (Uceda 1997, 2001, 2010), the Huaca Cao Viejo at the El Brujo Archaeological Complex (Franco et al. 1994, 1999, 2010), and at San José de Moro (Castillo 1993, 1996). Several other projects (see Quilter and Castillo 2010) also played important roles in deepening, broadening, and complicating our perspectives on the Moche and leading to the current reevaluation.

At Sipán and San José de Moro, the discovery of high-status burials with special costumes and regalia supported the idea that priests and priestesses dressed as deities and carried out rituals shown in art (Alva and Donnan 1993; Castillo 1993, 1996). ${ }^{2}$ Subsequent discoveries also suggested that burials at other sites might have been costumed as gods and goddesses (Atwood 2010; Mujica Barreda 2007). Donnan (2010) has recently argued that the Sacrifice Ritual, formerly known as the Presentation Theme, was a ceremony practiced throughout the North Coast and that it had great time depth, from early to late Moche times.

Another important, new view of Moche came from the exposure of wall murals on the front terraces of the Huaca de la Luna (Uceda 2010) and the Huaca Cao Viejo (Mujica Barreda 2007). The last major construction phase at Cao Viejo was carried out with the same artistic program, with minor variations, as the last three building phases at Luna, and the sites share the same general architectural plan. Two walls depicting warriors leading naked, bound prisoners in a victory parade at ground level with a row of identically costumed human figures holding hands on the terrace wall above them focused renewed attention on the martial nature of Moche society.

In addition to the murals, two plazas were excavated at Huaca de la Luna that contained the 
remains of numerous sacrificial victims (Bourget 2001). Skeletal studies revealed that these victims were all males, mostly in their late teens and twenties, many with injuries suggesting combat wounds that had been received a few to several days prior to their deaths (Verano 1998, 2001).

The concept of a Moche expansionist state had drawn upon the frequent depiction of combat in Moche art and interpreted it as representing imperial growth through military conquest. The almost simultaneous discovery of the rich burials of Moche elite dressed as gods, the depictions of warriors on the temple walls, and the sacrifices were interpreted as closely related. Together, they reinforced the concept of warfare and human sacrifice as a key element in Moche state religion (Donnan 2010).

For those who maintained the idea of the Moche as a dominant conquest state that imposed a "Pax Mochica," the Sacrifice Ceremony was an elaborately staged and planned selection of Moche youths for sacrifice and not the results of agonistic combat. Other specialists (Donnan 2010) interpret the Sacrifice Ceremony complex as a ritual "glue" that held independent polities together in a common culture, a topic to be discussed at greater length below.

The concept of a single Moche state throughout the entire North Coast did not go unchallenged (see Isbell and Schreieber 1978). Alfred Kroeber (1930) and Paul Kosok (1965) both suggested that the far north coast valleys, from the Jequetepeque Valley northwards, had different environmental conditions and developmental trajectories than those to the south. Richard Schaedel (1985) also argued against a Moche state, suggesting that it was, at best, a paramount chiefdom because labor was tributary, not coercive, in a temple-economy (Tempelwirschaft), not an autonomous governmental system. In a similar vein, Garth Bawden $(1996,2004)$ argued that Moche was primarily a religious system that served to link elites throughout the north coast. Both Schaedel and Bawden, however, made their critiques within the framework of explicitly neoevolutionary theory, Schaedel via his interest in the criteria for chiefdoms versus states and Bawden through his historical materialist approach to prehistory.

In the 1990s, research by Peter Kaulicke (1991) in the upper Piura Valley, far from the Moche heartland, revealed distinctly Moche jewelry with non-
Moche, Vicús ceramics, while investigations at Pampa Grande by Izumi Shimada (1994) supported his view of a different cultural trajectory for the $\mathrm{La}$ Leche-Lambayeque Valley. Luis Jaime Castillo and Christopher Donnan (1994) demonstrated that the Larco ceramic sequence was not applicable for the Jequetepeque Valley, in particular, as well as the upper North Coast, in general. These studies have led to the current "normative science" view of two Moche realms, a Northern Moche with independent polities, one or more in each valley, and an expansive Moche state based at the Huacas de Moche in a Southern Moche region.

Michael Moseley (2001:195-196), in his revised edition of his general introduction to Andean prehistory, suggests that the Moche state's rule north of the Chicama Valley was, at best, indirect, and concludes that the northern polities were largely independent and "formed only a loose confederation with the south by a vibrant ideology" (Moseley 2001:196). The southern state and Moche in general are still seen, however, as representing a "remarkable evolution in statecraft ranging from taxation and labor organization to art and ideology" (Moseley 2001:196). And, more recently, Steve Bourget (quoted in Atwood 2010) has reasserted the argument that Moche was a single state stretching both north and south based on similarities in the burial costumes and regalia of high-status burials on either side of the divide.

We believe that the data did not support the idea of a single expansive state using the neoevolutionary criteria on which the concept was developed even at the time it was being created. Below we review and critique the criteria and data that are typically used to endorse the state to demonstrate that a single Moche state, north, south, or altogether, is not supportable. We will then discuss how we might reconsider Moche.

\section{Evaluating Claims for the Multi-Valley, Expansive Moche State}

Assumptions concerning the existence of a Moche state that expanded from the Huacas de Moche were based on several interrelated data sets. The assumptions and data included: (1) a corporate Moche ceramic style originating at Huacas de Moche; (2) a corporate Moche architectural style; (3) standardized construction techniques associ- 
ated with a labor tax; (4) an emphasis on militarism as seen in iconography; (5) a standardized religion also seen in iconography; (6) survey data that showed the rapid appearance of Moche traits, especially ceramics and architecture, in the "provinces." All of these were seen as supporting the idea that Moche was an organized political entity with a formal government that consisted of a ruling class, a bureaucracy, and commoners. The political system was closely linked to a state religion with its own organization or the two were inseparable in a single theocratic state system. In short, a "classic" definition of states as discussed by neoevolutionary theorists (e.g., Fried 1967; Jones and Kautz 1981; Service 1962, 1975), especially from the 1960 s into the 1980 s, was attributed to Moche, albeit with different scholars taking somewhat different approaches.

Here, we discuss each of these data sets and the assumptions and interpretations associated with them. In some cases alternate interpretations could have been made thirty or more years ago, in other cases, research since the 1980 s has been critical in changing our views.

\section{Corporate Ceramic Styles}

We already have noted that research in the $1990 \mathrm{~s}$ demonstrated that the Larco five phase ceramic chronology did not hold for the Northern Moche region. The impasse of sorting out unprovenienced ceramic collections was overcome by the growth of new field projects after Sipán. Further research since the 1990 s has continued to demonstrate diversity-claimed Moche "sub-styles" (Makowski 2010) - in what formerly was thought to be a standardized class of Moche fine wares. Most specialists no longer maintain the concept of a single, corporate Moche style. This view is more strongly held for the Northern Moche realm but we propose that evidence is growing for the same situation in the Southern Moche region.

\section{Corporate Architectural Style}

Many large huacas on the North Coast that had no evidence to the contrary were assumed to be Moche structures. Gordon Willey (1953:397) interpreted Huancaco in the Virú Valley as the regional capital after the Moche conquest, for example. More recent work by Steve Bourget (2010), however, led him to conclude (maintaining the idea of an expan- sive state) that the site represents a short-lived cultural tradition that may have been a response or resistance to the encroaching Moche in evidence at Huaca de la Cruz, elsewhere in the valley.

If we assume that a state could be inferred by an architectural canon then none appears to exist for Moche. Proceeding south, from Virú, there is no substantial architecture in the Chao Valley (Cárdenas Martín 1976) at all, only a small platform with "Moche"-like features (Kent et al. 2009:175). In the Santa Valley three sites with large architecture have been studied in detail (Chapdelaine 2008, 2010, Chapdelaine et al. 2009; Wilson 1983:247, 1988:217). The architecture appears distinctively local, not resembling anything anywhere else. From Pañamarca (Bonavia and Makowski 1999; Schaedel 1951), the southernmost known Moche complex, in the Nepeña Valley, to the Huaca Fortaleza, far to the north in the La Leche Valley (Haas 1985; Shimada 1994), Moche architecture appears to be highly variable.

Some might argue that variability in temple architecture can be expected within a state system by accommodation to local styles or by the appropriation of older temples for the new religion, but this is not how claims for a Moche as a state proceeded. Instead, pointing to Moche traits and ignoring non-Moche features has been the mode of discourse with the assumption that a Moche state would have imposed its religion and distinct architectural canons upon a local populace.

\section{Construction Techniques and Labor Tax}

Another claim for Moche statehood is based on huaca construction techniques and the use of marked adobe bricks (Hastings and Moseley 1975; Shimada 1994:162-166). It was claimed that huacas and other large structures were built in segmented sections of thick, column-like units of bricks separated by seams from one another that might express the labors of separate work gangs, perhaps composed of laborers from specific social units. As the Inca state demanded tribute in the form of labor from its subjects, researchers interpreted the segmental units in Moche huacas as a form of labor tax, as well.

In addition, distinctive marks, such as lines, dots, and semi-circles on the flat sides of adobe bricks, made while the clay was still wet, have been noted in some huacas. These were interpreted as 
tallies to keep track of labor contributions and fit well with the concept of a labor tax as seen in the segmental construction units, presumably made by members of different social groups.

Segmental construction units cannot, by themselves, be sufficient evidence for a state. The idea that segmental construction units equate with separate work gangs is an inference even if it is a reasonable one. More importantly, even if construction in segments was a product of separate work crews, such social units were not necessarily under state control. In addition, a recent review of construction techniques at huacas in the Chicama Valley found that very few are built using the segmental system but rather, a wide variety of techniques were employed.

Studies of marked adobes only suggest that work gangs likely existed which contributed to building projects and do not point to a state authority. Although marked bricks have been discussed extensively (e.g., see Shimada 1994), how they link to social organization remains uncertain. Similar to segmental construction units, the use of marked adobes appears to have been quite limited based on Koons' recent review of the subject.

\section{Militarism}

Military themes are quite common in Moche art. Hilltop fortified sites and hillside residential sites were identified quite early but they often were not assumed to be Moche. This was partly due to lack of excavations at such sites until quite recently (Billman 2002, 2010), and also due to the identification of serving-ware ceramics, especially the Castillo Series, collected during surveys, as typical of Gallinazo, the culture that preceded Moche (Strong and Evans 1952); the sites they were found on were thus also assumed to be Gallinazo, predating Moche. Recent research (Millaire 2009), however, suggests that these ceramics were widespread and of long duration among peoples who otherwise preferred different fine wares identified as Gallinazo or Moche. This means that many of these sites, separated out as Gallinazo or Moche, may have been contemporary and that warfare cannot be specifically linked to a Moche expansion.

Warriors are commonly depicted on Southern Moche ceramics. In the 1990 s, a still unresolved debate developed as to whether Moche warfare was primarily ritual or agonistic. Some hold that arranged battles were held for the taking of prisoners (e.g., Hocquenghem 1987; Makowski 1996, 2010; Topic and Topic 1997a, 1997b). Others (Quilter 2002,2008; Verano 2001) argue that prisoners of war used as sacrificial victims left to rot in plazas more strongly suggest a complex political landscape that included warfare undertaken for political reasons (pace Arkush and Stanish 2005) between groups of Moche rather than as highly stylized religious acts. Although the debate is not fully settled, the current view of most scholars seems to be that while some ritual battles may have been staged, combat for political aims did take place.

No one has provided a convincing argument that warfare was due to state expansion from Huacas de Moche. There is considerable evidence that at least some combat took place between coastal peoples and highlanders making incursions into the lower valleys (Billman 2002:392; see Lau 2011). No one has demonstrated that such incursions were resisted by a state, which we would expect if such a polity had jurisdiction over the entire North Coast of Peru.

\section{The Moche Religious System}

The ritual program that appears to have culminated in the exchange of goblets by deity impersonators, known as the Sacrifice Ceremony, seems to have been practiced over many years and throughout the region where Moche ceramics and other remains are found today. This common set of deities shown in art suggests a shared pantheon and general ritual practice with particulars that varied due to local preferences and changes through time. The fact that at San José de Moro, over time, several different women were buried dressed in the costume of the "Priestess" or "Woman" of the Sacrifice Ceremony (Castillo 1993, 1996) suggests that the people who gathered at the site saw this deity as the primary one for this center.

Other themes and scenes in Moche art strongly suggest that different gods and narratives were depicted, such as the personages shown in a hero tale (Golte 1994). Just as ceramic styles were conflated and thought to have all been Moche and just as Castillo wares and other styles are now being separated out and distinguished from a generalized Moche palimpsest, we suggest that the same holds for iconography. The difficulties of determining 
whether slightly different portrayals of similar looking deities indicates one or several gods are due to the fact that they represent regional and temporal variations of similar deities interpreted differently, perhaps in a manner similar to the Olympic Pantheon at different Classical Greek city-states (see Quilter 2010).

The apparent variability in deities runs counter to the notion of the Sacrifice Ceremony gods and associated rituals as the religion of an expansive state. If such were the case, we would expect a much more standardized system than presently appears to have existed. The available evidence is better explained, in general, as a shared religious system with local variations. ${ }^{3}$ Even if the Sacrifice Ceremony was practiced throughout the north coast, this does not necessarily imply that a state or empire spread it any more than the spread of a number of religious systems that have done so without the agency of a state (see Patterson 1971).

\section{Surveys and the Rapid Moche Expansion}

Partly for brevity's sake, we will focus on surveys in Southern Valleys where the concept of a Moche state presently endures. Gordon Willey's survey and settlement pattern analysis (1953) in the Virú Valley project inspired other, similar studies on the North Coast. Over the last 50 years many valleys with Moche material culture have been surveyed.

In the Virú Valley, Willey (1953:393) saw human population in the upper valley shifting down stream as it grew and filling the valley with a population peak in Late Gallinazo, just before the appearance of Moche ceramics. The eve of Moche arrival also was the first time "Agglutinated Villages" and pyramid complexes were built. Both of these, as well as cemeteries, increased significantly in the Huancaco period, the local term for the Moche era (Willey 1953:177, 233, 228).

The same patterning as seen in the Virú was identified in all of the southern valleys subsequently surveyed including Nepeña (Daggett 1983, 1984; Proulx 1973, 1985), Santa (Donnan 1973; Wilson 1983, 1988), Moche (Billman 1996, 2002), and Chicama (Russell and Leonard 1992). General trends can be summarized as follows: (1) populations reached their maxima, to date, shortly before the appearance of Moche style ceramics and architecture as defined by the researchers; (2) the population maxima co-occurred with substantial growth of irrigation systems in the lower valleys; (3) Moche sites first appeared in greatest numbers in the mid-to-lower valleys and fine ware ceramics were located primarily in cemeteries and ceremonial centers; (4) a growth in the variety of site types took place including an increase in agglutinated habitation sites; (5) cemeteries greatly increased in number.

Most of the research discussed above was based on few to no radiocarbon dates, used the Larco ceramic sequence, and followed the cultural phases of the Virú Valley research. The reevaluation of the Castillo Series as contemporary with Moche (see Millaire with Morlion 2009), however, means that the models of population increase, up-valleyto-lower valley settlement shifts, and the "arrival" of the Moche who built huacas in the lower valleys can no longer be supported. So, too, reanalysis of radiocarbon dates (Lockard 2009; Quilter et al. 2012) and recognition of the limitations of the Larco sequence, when considered in relation to weakly supported cultural sequences from surveys in southern valleys, combine to undermine previous models of Moche expansion. While some changes are to be expected over the centuries, valley appears to have reached population capacities in relatively uniform, similar manners through local growth and, likely, from highland immigrants or invaders.

\section{Reconsidering Moche}

By the criteria of neoevolutionary theory, the data do not support the proposition that Moche was an expansive state based at the Huacas de Moche. Although researchers prior to the $1990 \mathrm{~s}$ did not have as much information as is available today, "Moche" was never defined. It was assumed that what was or was not Moche was apparent in the archaeological record. The idea of a Moche state developed early on and once in place it was never challenged, including the notion that there was a distinct, basically secular, organ of governmental administration. Instead, research reconfirmed what was already known. Archaeological remains were interpreted as the expressions of traits necessary to classify the Moche as a state rather than queried for alternate interpretations while missing evidence, such as large-scale storage facilities or a clear state bureaucracy in the form of indisputable state gov- 
ernmental officials, were ignored. Those scholars who did suggest alternative interpretations (e.g., Bawden 1996; Schaedel 1985) did so within the neoevolutionary paradigm that used these criteria. Attempts to shift the origins of the first Andean states to other or earlier cultures will not be successful if similar unquestioned assumptions are employed (Millaire 2011b).

A number of contemporary scholars, notably Tom Dillehay and others (2009), Krzysztof Makowski (2010), Edward Swenson (2006, 2007, 2011), Gregory Lockard (2009), Claude Chapdelaine (2011), Jean-François Millaire (2010a, 2010b), and Izumi Shimada (2010) have raised issues that directly or indirectly challenge the notion of a single, hegemonic Moche state. Furthermore, there is widespread, although not total, agreement among Moche specialists that Moche north of the Chicama Valley was not organized as a single entity (Castillo and Uceda 2008). Those who still maintain the concept of a Moche state see it as present in the Southern Moche region, from Chicama to Nepeña. Our point in this essay, however, is that the evidence does not support the idea of Moche as a single political entity either on the entire North Coast or only a part of it.

The "classic" neoevolutionary criteria for statehood (Spencer and Redmond 2004:175) usually consist of three essentials: (1) a four-tier regional settlement-size hierarchy; (2) royal palaces and temples; and (3) the conquest/subjugation of distant territories. We take note of an anonymous reviewer of an earlier draft of this article who pointed out that states are inherently unstable and short lived, and that the essence of statehood is a highly visible centralizing strategy that extends outward from the center of a polity to make its mark on its subject peoples and territories. We agree, and it is certainly reasonable to understand how the evidence seemed to overwhelmingly point to Moche statehood in the past. But the evidence does not support that view now.

Because there are so many different definitions of the state, we object to attempts to get around the issue of Moche statehood by arguing that it was a different kind of state than that proposed by one scholar or another. Indeed, we suggest that the constant reworking of what a prehistoric state was like and how it might be identified archaeologically as discussed in the archaeological literature over the last half-century and more is not a sign of scholarly rigor but a floundering attempt to fit square pegs into round holes. The definitions become so general as to be of only heuristic value.

For us, ultimately the critical issue for a better understanding of the archaeological issue is not whether Moche was or was not a state, since someone can always argue that it was by crafting a definition that will fit the data. We believe that a close examination of how economic and political power was distributed, marshaled, and employed within spatiotemporal boundaries will lead to a richer understanding of the Moche and other archaeological cultures. Given the fact that Moche, as currently defined, existed for centuries, we should assume that political economies - the ways in which labor and resources were produced and distributed-varied considerably through time and space.

Undoubtedly, the Moche phenomenon had a political dimension. Sabine MacCormack (1991:156-157) writes that for the Inca, politics and religion were "coextensive," that there was an "interdependence of Inca politics and religion." The same holds true for many - perhaps most, perhaps all-Andean prehistoric cultures, and we propose that the task of archaeologists is to identify the ways in which religion and politics were organized and interpenetrated each other in any particular prehistorical instance.

A second consideration is the point made by Tom Dillehay (2001) that huaca centers were only one political player on the North Coast of Peru. There are sites that appear to be more urban than ritual, such as Mocollope in the Chicama Valley, for example, or the rich tomb at La Mina (Narváez 1994), which apparently was placed in a non-huaca setting. There are sites of refuge as well as forts and there are numerous hillside settlements. Many hillside settlements have been documented recently in the Jequetepeque (Castillo 2010; Dillehay et al. 2009; Swenson 2007) and Moche valleys (Billman 1996), and we have observed them as extensive in the Chicama. The up-valley, "pre-Moche" occupations and the "Moche" occupations in lower valleys that were distinguished in many of the early surveys now must be reevaluated and may possibly have been contemporary. Valleys likely were densely occupied from early times and it is in this context that Moche developed rather than spread- 
ing from a single valley into relatively lightly occupied valleys with a subsequent moving of subject populations. These data suggest that politics occurred through many different agents in many different locales in which the huaca centers were important but not the only actors.

We also maintain that the foundation of politics in the Andes, as in all preindustrial societies, was localized kin groups. Colonial documents state that the indigenous population in the Chicama Valley was organized into a series of ranked and nested moieties known as parcialidades based on dualistic organization (Netherly 1984, 1988, 1993; Ramírez 1995, 1996). This kind of sociopolitical organization is fractal in nature so that both combining small groups into larger entities and the fissioning of large groups into smaller ones occur relatively easily because the basic organizational structure is replicated at all scales. While we cannot be sure that this system was in operation seven or more centuries prior to the era of the Colonial documentation, we suggest that it is a better working model than abstract notions of the state.

Susan Ramirez (1996:60) notes that, at the time of the Spanish conquest, although land was not owned and the concept of territory did not exist, north coast huacas were "owned" by the cacique principal (principal "chief") of a parcialidad because its construction was the result of labor that the cacique controlled. If the Moche system had been similar to the organization of the north coast at contact, we would expect to see material correlates between huaca centers under the rule of a cacique principal. The variations in sizes, formats, and material culture at the huaca centers, as are being revealed in current research, may thus be related to sociopolitical systems that were tied to local kin groups and their caciques. The success of some huacas that grew in size over many centuries and the failures of others to last more than a generation or two may have been due to the rise and fall of kin groups and their leaders in a complex political landscape. $^{4}$

While the people of the huacas were political agents, they acted through religious rituals and, likely, the production, and, almost certainly, the distribution of specialized goods in the forms of distinctive ceramics, metals, and other high-status goods and signs of affiliation that marked each huaca, its cult, and its followers as different from others. We believe that the "power" of many huacas was centripetal, attracting followers by means of rituals at ceremonial centers or serving as arbitrators of local disputes as Castillo (2010) has suggested for San José de Moro. At other huacas centrifugal forces may have been at work, such as at the Huacas de Moche and, later, the El Brujo Complex, where the military themes in murals suggest that the temple priests were actively engaging in warfare. These concepts of "centripetal" and "centrifugal" are presented merely to suggest new ways to think of how huacas "worked," and in many cases, of course, they were both pulling in and pushing out social, political, and economic forces at the same time.

Given the distribution of resources in coastal valleys, we also suggest that politics in and between the valleys often involved access to water and the relationship between fishing and agricultural communities. Although Susan Ramírez (2005) makes a convincing argument that much of Inca concerns in governing focused on people rather than territory, we suggest that water, irrigation systems, and the lands that they watered would have been critical issues of negotiation and confrontation in Peru. Perhaps some Moche huaca systems at some times were involved in systems of water distribution, possibly similar to temple management of irrigation in Bali (Lansing 1993) in which the timing of when field sections were irrigated with water were linked to when rituals were held at associated temples. The fact that some of the largest huaca centers are located near the ends of the irrigation systems rather than at the crucial aqueduct junctures upstream, suggests that lower valley populations may have employed the power of the temple rituals as a way to finesse a marginal position in the valley into a role of control.

There may have been alliances or conquests between two or more huacas, as in evidence in the close similarities between the Huaca de la Luna and the Huaca Cao Viejo. There may have been large centers that controlled smaller centers within or beyond a single valley. Some huacas may have been the seats of oracles with secondary centers far afield, as was the case in Inca times (Gose 1996, Patterson 1985a, 1985b; Quilter 2010). All of these are possible and we believe, likely, to have characterized north coast societies at various points during the Moche era on the North Coast. It is also 
important to remember that in lasting over centuries the Moche phenomenon was constantly changing and in flux.

In recent years many scholars have challenged neoevolutionary theory (Pauketat 2007; Smith 2003; Yoffee 2005). All state that simplistic neoveolutionary models pigeonhole cultures and societies into predefined types and do not account for the unique histories and the complex power relations of people and the places that they occupied. Following this precedent and having critiqued the concept of a Moche state, we are reluctant to suggest what Moche was as the term might be defined in a number of ways. But we feel obliged to make an attempt at a definition. We suggest a modification of Bawden's (1996) proposal of Moche as a religious system that served to enable the evolution of the state. We suggest that Moche was a religious system that realigned the political economies and social relations of North Coast societies. Just as the introduction of Christianity into Western Europe reshuffled social, political, and economic relations among independent political entities, so did Moche. The difference, however, is that whereas Christianity was a foreign system that inserted itself into a region, Moche appears to have been a relatively local creation although it may have first developed in the Northern Moche region and spread southwards. ${ }^{5}$

We assert the timing of the appearance of Moche traits is as important as anything else in defining what Moche was. In other words, there appear to have been multiple "Moches" in time as well as in space. An early Moche phenomenon in the mid-tolate fourth century appears to have spread from the northern valleys southwards. Then the Huacas de Moche reinterpreted Moche and spread it farther south (and to Chicama) in the sixth century. In a final Moche phase, post A.D. 650, the Moche tradition was again reformulated in processes still to be clarified and with complicated regional variations currently being investigated (Castillo 2010; Koons 2011; Swenson 2011). By A.D. 900, however, the Moche tradition appears to have ended completely.

In the last half-century, many archaeologists have diligently worked at sites throughout the north coast to build one of the best archaeological records of past human behavior in South America, and the efforts of those who saw a state society helped us to attain the vision we have today. It is because of those investigations that the concept of the Moche expansive state arose and equally so, the reason why it has now fallen and continues to be critically evaluated (Lockard 2009; Quilter and Castillo 2010; Swenson 2007). Some will be sad to see the Moche state collapse and others may resist its downfall. We suggest, however, that current evidence overwhelmingly points to a much more complicated picture of the past in "Mochelandia" than has previously been considered when the state model was the dominant paradigm. What we lose in the state's fall we gain in a richer understanding of the past.

Acknowledgments. Thanks to the editors and editorial staff of Latin American Antiquity for their work on this submission. Thanks also to Luis Jaime Castillo for help with the Spanish abstract. We offer special thanks to Ms. Linda Ordogh of the Peabody Museum, Harvard University, for extraordinary efforts in last minute work on the manuscript that was sorely needed and finely done. Thanks also to Richard L. Burger, Luis Jaime Castillo B., Rowan Flad, Jeffrey Frost, Adam Herring, Steven LeBlanc, Matthew Liebmann, Daniel H. Sandweiss, Lisa Trever, and Jason Ur who all read earlier drafts of this article and offered highly valuable commentary on them even when they did not agree with our arguments. Those comments helped us to strengthen our work as did the comments of anonymous reviewers of this and an earlier draft. We also wish to recognize and thank all of the scholars, past and present, who have worked and are working on Moche topics. In particular, all current "Mochicólogos" are highly collegial and generous in sharing their data and views. We offer this article to them in the hopes that our criticisms of current models will be accepted as our attempt to contribute to our common interests in better understanding the Moche and with full appreciation of their efforts in also doing so.

\section{References Cited}

Alva, Walter

1988 Discovering the New World's Richest Unlooted Tomb. National Geographic 147(4):510-548.

1994 Sipán. Cervecería Backus y Johnston, Lima.

1999 Sipán, descubrimiento e investigación. Cervecería Backus y Johnston, Lima.

Alva, Walter, and Christopher B. Donnan

1993 The Royal Tombs of Sipán. Fowler Museum of Cultural History, University of California, Los Angeles.

Arkush, Elizabeth, and Charles Stanish

2005 Interpreting Conflict in the Ancient Andes. Current Anthropology 46:3-28.

Atwood, Roger

2010 Lord of Úcupe. Archaeology 63:21.

Bankes, George

1980 Moche Pottery from Peru. British Museum, London.

Bawden, Garth

1996 The Moche. Blackwell, Cambridge, Massachusetts. 
2004 The Art of Moche Politics. In Andean Archaeology, edited by Helaine Silverman, pp. 116-129. Blackwell, Malden, Massachusetts.

Benson, Elizabeth P.

1972 The Mochica: A Culture of Peru. Praeger, New York and Washington, D.C.

Berezkin, Yuri

1980 An Identification of Anthropomorphic Mythological Personages in Moche Representations. Ñawpa Pacha 18:1-26.

1987 Moche Society and Iconography. In Pre-Columbian Collections in European Museums, edited by Anne-Marie Hocquenghem, Peter Tamási, and Christine Villain-Gandossi, pp. 270-277. Akadémiai Kiadó, Budapest.

1990 Estructura social de la civilización mochica y su reflejo en la iconografía [in Russian with a Spanish abstract]. In Problemy arkheologii $i$ drevnei istorii stran Latinskoi Ameriki, edited by Vladimir A. Bashilov, pp. 223-247. Nauka, Moscow.

Billman, Brian R.

1996 The Evolution of Prehistoric Political Organizations in the Moche Valley, Peru. Unpublished Ph.D. dissertation, Department of Anthropology, University of California, Santa Barbara.

2002 Irrigation and the Origins of the Southern Moche State on the North Coast of Peru. Latin American Antiquity 13:371-400.

2010 How Moche Rulers came to Power. In New Perspectives on Moche Political Organization, edited by Jeffrey Quilter and Luis Jaime Castillo Butters, pp. 181-200. Dumbarton Oaks Research Library and Collection, Washington, D.C.

Bonavia, Ducco, and Krzysztof Makowski

1999 Las pinturas murales de Pañamarca. Iconos: revista peruana de conservación, arte y arqueología 2:40-54.

Bourget, Steve

2001 Rituals of Sacrifice: Its Practice at Huaca de la Luna and its Representation in Moche Iconography. In Moche Art and Archaeology in Ancient Peru, edited by Joanne Pillsbury, pp. 89-109. National Gallery of Art, Washington, D.C.

2010 Cultural Assignations during the Early Intermediate Period: The Case of Huancaco, Virú Valley. In New Perspectives on Moche Political Organization, edited by Jeffrey Quilter and Luis Jaime Castillo Butters, pp. 199-220. Dumbarton Oaks Research Library and Collections, Washington, D.C.

Cárdenas Martín, Mercedes

1976 Informe preliminar del trabajo de campo en el Valle de Chao (Departamento de La Libertad). Instituto Riva Agüero, Seminario de Arqueología, Pontificia Universidad Católica del Perú, Lima.

Castillo Butters, Luis Jaime

1989 Personajes míticos, escenas y narraciones en la iconografía mochica. Fondo Editorial de la Pontificia Universidad Católica del Perú, Lima.

1993 Prácticas funerarias, poder e ideología en la sociedad moche tardía: El Proyecto Arqueológico San José de Moro. Gaceta Arqueológica Andina 23:61-76.

1996 La tumba de la sacerdotisa de San José de Moro. Centro Cultural de la Pontificia Universidad Católica del Perú, Lima.

2010 Moche Politics in the Jequetepeque Valley; A Case for Political Opportunism. In New Perspectives on Moche Political Organization, edited by Jeffrey Quilter and Luis Jaime Castillo Butters, pp. 83-109. Dumbarton Oaks Research Library and Collection, Washington, D.C.
Castillo Butters, Luis Jaime, and Christopher B. Donnan 1994 Los mochicas del norte y los mochicas del sur. In Vicús, edited by Krzysztof Makowski, Christopher B. Donnan, and Iván Amaro Bullon, pp. 143-176. Banco de Crédito del Perú, Lima.

Castillo Butters, Luis Jaime, and Santiago Uceda Castillo 2008 The Mochicas. In Handbook of South American Archaeology, edited by Helaine Silverman and William H. Isbell, pp. 707-730. Springer, New York.

Castillo Butters, Luis Jaime, and Jeffrey Quilter

2010 Many Moche Models: An Overview of Past and Current Theories and Research on Moche Political Organization. In New Perspectives on Moche Political Organization, edited by Jeffrey Quilter and Luis Jaime Castillo B.,pp. 1-16. Dumbarton Oaks Research Library and Collection, Washington, D.C.

Chapdelaine, Claude

2008 Moche Art Style in the Santa Valley: Between Being "à la mode" and Developing a Provincial Identity. In The Art and Archaeology of the Moche: An Ancient Andean Society of the Peruvian North Coast, edited by Steve Bourget and Kimberly L. Jones, pp. 129-152. University of Texas Press, Austin.

2010 Moche Political Organization in the Santa Valley: A Case of Direct Rule Through Gradual Control of the Local Population. In New Perspectives on Moche Political Organization, edited by Jeffrey Quilter and Luis Jaime Castillo Butters, pp. 250-277. Dumbarton Oaks Research Library and Collections, Washington, D.C.

2011 Recent Advances in Moche Archaeology. Journal of Archaeological Research (19): 191-231.

Chapdelaine, Claude, Victor Pimentel, and Jorge Gamboa

2009 Gallinazo Cultural Identity in the Lower Santa Valley: Ceramics, Architecture, Burial Patterns, and Sociopolitical Organization. In Gallinazo: An Early Cultural Tradition on the Peruvian North Coast, edited by JeanFrançois Millaire with Magali Morlion, pp. 181-206. Cotsen Institute of Archaeology Press, University of California, Los Angeles.

Collier, Donald

1955 Cultural Chronology and Change as Reflected in the Ceramics of the Virú Valley, Peru. Fieldiana Anthropology v. 43. Field Museum of Natural History, Chicago.

Daggett, Richard

1983 Megalithic Sites in the Nepeña Valley, Peru. In Investigations of the Andean Past, edited by Daniel H. Sandweiss, pp. 75-97. Cornell University Latin American Program, Ithaca, New York.

1984 The Early Horizon Occupation of the Nepeña Valley, North Central Coast of Peru. Unpublished Ph.D. dissertation. Department of Anthropology, University of Massachusetts, Amherst.

Dillehay, Tom D.

2001 Town and Country in Late Moche Times: A View from Two Northern Valleys. In Moche Art and Archaeology in Ancient Peru, edited by Joanne Pillsbury, pp. 259-283. National Gallery of Art, Washington, D.C.

Dillehay, Tom D., Alan L. Kolata, and Edward Swenson

2009 Paisajes culturales en el Valle de Jequetepeque: los yacimientos arqueológicos. Ediciones Sian, Trujillo and Lima. Donnan, Christopher B.

1973 Moche Occupation of the Santa Valley, Peru. University of California Publications in Anthropology Vol. 8. University of California Press, Berkeley.

1976 Moche Art and Iconography. Latin American Studies 33. University of California, Los Angeles, Latin American Center, University of California, Los Angeles. 
1978 Moche Art of Peru: Pre-Columbian Symbolic Communication. Museum of Cultural History, University of California, Los Angeles.

2009 The Gallinazo Illusion. In Gallinazo: An Early Cultural Tradition on the Peruvian North Coast, edited by Jean-François Millaire with Magali Morlion, pp. 17-32. University of California, Los Angeles, Cotsen Institute of Archaeology Press, Los Angeles.

2010 Moche State Religion: A Unifying Force in Moche Political Organization. In New Perspectives on Moche Political Organization, edited by Jeffrey Quilter and Luis Jaime Castillo Butters, pp. 47-69. Dumbarton Oaks Research Library and Collection, Washington, D.C.

Donnan, Christopher B., and Carol J. Mackey

1978 Ancient Burial Patterns of the Moche Valley, Peru. University of Texas Press, Austin.

Donnan, Christopher B., and Guillermo A. Cock (editors)

1986 The Pacatnamu Papers, Vol. 1. Museum of Cultural History, University of California, Los Angeles.

1997 The Pacatnamu Papers, Vol. 2. The Moche Occupation. Fowler Museum of Cultural History, University of California, Los Angeles.

Fagan, Brian M.

2008 World Prehistory: A Brief Introduction. $7^{\text {th }}$ ed. Pearson-Prentice Hall, Upper Saddle River, New Jersey.

Franco Jordán, Régulo, Cesar Gálvez Mora, and Segundo Vásquez Sánchez

1994 Arquitectura y decoración mochica en la Huaca Cao Viejo, Complejo El Brujo: resultados preliminares. In Moche: propuestas y prospectivas. Actas del Primer Coloquio Sobre la Cultura Moche (Trujillo, 12 al 16 de abril de 1993), Travaux de l'Institut Francais d'Etudes Andines, edited by Santiago Uceda and Elías Mujica t. 79, pp. 147-180. Universidad Nacional de la Libertad, Trujillo, Peru, and Instituto Francés de Estudios Andinos; and Asociación Peruana para el Fomento de las Ciencias Sociales, Lima.

1999 Tumbas de cámara moche en la Plataforma Superior de la Huaca Cao Viejo, Complejo el Brujo. Programa Arqueológico Complejo El Brujo, Boletín 1:5-29.

2010 Moche Power and Ideology at the El Brujo Complex and in the Chicama Valley. In New Perspectives on Moche Political Organization, edited by Jeffrey Quilter and Luis J.aime Castillo Butters, pp. 110-131. Dumbarton Oaks Research Library and Collection, Washington, D.C.

Fried, Morton $\mathrm{H}$.

1967 The Evolution of Political Society: An Essay in Political Anthropology. Random House, New York.

Golte, Jürgen

1994 Iconos y narraciones: la reconstrucción de una sequencia de imágenes moche. Instituto de Estudios Peruanos, Lima.

Gose, Peter

1996 Oracles, Divine Kingship, and Political Representation in the Inka state. Ethnohistory 43:1-32.

Haas, Jonathan

1982 The Evolution of the Prehistoric State. Columbia University Press, New York.

1985 Excavations on Huaca Grande: An Initial View of the Elite at Pampa Grande. Journal of Field Archaeology 12:391-409.

1987 The Exercise of Power in Early Andean State Development. In The Origins and Development of the Andean State, edited by Jonathan Haas, Sheila Pozorski, and Thomas Pozorski, pp. 31-35. Cambridge University Press, Cambridge.
Hastings, Charles M., and Michael E. Moseley

1975 The Adobes of Huaca del Sol and Huaca de la Luna. American Antiquity 40:196-203.

Hecker, Gisela, and Wolfgang Hecker

1985 Pacatnamú y sus construcciones: centro religioso prehispánico en la Costa Norte Peruana. Publicación dentro del proyecto de edición del legado científico de Heinrich Ubbelohde-Doering. M. Vervuert, Frankfurt.

Hocquenghem, Anne Marie

1987 Iconografía Mochica. Pontificia Universidad Católica del Perú, Fondo Editorial, Lima.

Isbell, William H., and Katharina J. Schreiber

1978 Was Huari A State? American Antiquity 43:372-379.

Jones, Grant D., and Robert R. Kautz

1981 The Transition to Statehood in the New World. Cambridge University Press, New York.

Kaulicke, Peter

1991 Moche, Vicús Moche, y el Mochica Temprano. Boletín del Instituto Francés de Estudios Andinos 21: 853-903.

Kent, Jonathan D., Teresa Rosales Tham, Victor Vásquez Sánchez, Richard A. Busch, and Catherine M. Gaither

2009 Gallinazo and Moche at the Santa Rita B Archaeological Complex, Middle Chao valley. In Gallinazo: An Early Cultural Tradition on the Peruvian North Coast, edited by Jean-François Millaire with Magali Morlion, pp. 167-179. University of California, Los Angeles, Cotsen Institute of Archaeology, Los Angeles.

Koons, Michele L.

2011 Moche in the Middle Horizon: Licapa II and the (Late?) Moche Phenomenon. Paper presented at a roundtable at Dumbarton Oaks, Times of Change, Changes of Time: An Inquiry about Absolute and Relative Chronologies of the Moche from Northern Peru, Washington, D.C.

Kosok, Paul

1965 Life, Land, and Water in Ancient Peru. Long Island University Press, New York.

Kroeber, Alfred L.

1930 Archaeological Explorations in Peru, Part II, The Northern Coast. Anthropology Memoirs Vol. 2, pp. 45-116. Field Museum of Natural History, Chicago.

Lansing, J. Stephen 1993 Emergent Properties of Balinese Water Temples, American Anthropologist 95:97-114.

Larco Hoyle, Rafael

1938 Los Mochicas, Tomo I. Casa Editora La Crónica y Variedades, Lima.

1939 Los Mochicas, Tomo II. Empresa Editorial Rimac, Lima.

1945 Los Mochicas (Pre-Chimu de Uhle y Early Chimu de Kroeber). Sociedad Geográfica Americana, Buenos Aires.

Lau, Geroge

2011 Andean Expressions: Art and Archaeology of the Recuay Culture. University of Iowa Press, Iowa City.

Lockard, Gregory D.

2009 The Occupational History of Galindo, Moche Valley, Peru. Latin American Antiquity 20:279-302.

MacCormack, Sabine

1991 Religion in the Andes: Vision and Imagination in Early Colonial Peru. Princeton University Press, Princeton.

Maisels, Charles

2010 The Archaeology of Politics and Power: Where, When, and Why the First States Formed. Oxbow Press, The David Brown Book Company, Oakville, Connecticut.

Makowski, Krzysztof

1996 Los seres radiantes, el águila y el búho. La imagen de la divinidad en la cultura mochica, s.II-VIII d.C. Costa 
Norte del Perú. In Imágenes y mitos. Ensayos sobre las artes figurativas en los Andes prehispánicos, edited by Krzysztof Makowski, Iván Amaro Bullon, and Max Hernández, pp. 113-133. Fondo Editorial SIDEA y Australis, Lima.

2010 Religion, Ethnic Identity, and Power in the Moche World: A View from the Frontiers. In New Perspectives on Moche Political Organization, edited by Jeffrey Quilter and Luis Jaime Castillo Butters, pp. 280-305. Dumbarton Oaks Research Library and Collection, Washington, D.C.

Millaire, Jean-François

2009 Gallinazo and the Tradición Norcosteña. In Gallinazo: An Early Cultural Tradition on the Peruvian North Coast, edited by Jean-François Millaire with Magali Morlion, pp. 1-17. University of California, Los Angeles, Cotsen Institute of Archaeology, Los Angeles.

2010a Moche Political Expansionism as Viewed from Virú: Recent Archaeological Work in the Close Periphery of a Hegemonic City-State System. In New Perspectives on Moche Political Organization, edited by Jeffrey Quilter and Luis Jaime Castillo Butters, pp. 221-249. Dumbarton Oaks Research Library and Collection, Washington, D.C. 2010b Primary State Formation in the Virú Valley, North Coast of Peru. Proceedings of the National Academy of Sciences (PNAS) 107(14):6186-6191.

Millaire, Jean-François, with Magali Morlion (editors)

2009 Gallinazo: An Early Cultural Tradition on the Peruvian North Coast. University of California, Los Angeles, The Cotsen Institute of Archaeology Press, Los Angeles. Moseley, Michael E.

1992 The Incas and their Ancestors: The Archaeology of Peru. Thames and Hudson, London and New York.

2001 The Incas and their Ancestors: The Archaeology of Peru. Revised ed. Thames and Hudson, London and New York.

Moseley, Michael E., and Kent C. Day

1982 Chan Chan, Andean Desert City. University of New Mexico Press, Albuquerque.

Mujica Barreda, Elías

2007 El Brujo: Huaca Cao, centro ceremonial moche en el Valle de ChicamalEl Brujo: Huaca Cao, A Moche Ceremonial Center in the Chicama Valley. Fundación Wiese. Lima.

Narváez, Alfredo

1994 La mina: una tumba Moche I en el Valle de Jequetepeque. In Moche: propuestas y perspectivas. Actas del Primer Coloquio sobre la Cultura Moche (Trujillo, 12 al 16 de abril de 1993), Travaux de l'Institut Français d'Etudes Andines t. 79, edited by Santiago Uceda and Elías Mujica, pp. 59-81. Universidad Nacional de la Libertad, Trujillo, Peru, and Instituto Francés de Estudios Andinos y Asociación Peruana para el Fomento de las Ciencias Sociales, Lima.

Netherly, Patricia J.

1984 The Management of Late Andean Irrigation Systems on the North Coast of Peru. American Antiquity 49:227-254.

1988 From Event to Process: The Recovery of Late Andean Organization Structure by Means of Spanish Colonial Written Records. In Peruvian Prehistory: An Overview of the Pre-Inca and Inca Society, edited by Richard W. Keatinge, pp. 257-275. Cambridge University Press, Cambridge.

1993 The Nature of Andean State. In Configurations of Power: Holistic Anthropology in Theory and Practice, edited by John S. Henderson and Patricia J. Netherly, pp. 11-35. Cornell University Press, Ithaca, New York.
Patterson Thomas C

1971 Chavín: An Interpretation of Its Spread and Influence. In Dumbarton Oaks Conference on Chavin, edited by Elizabeth P. Benson, pp. 29-48. Dumbarton Oaks Research Library and Collection, Washington, D.C.

1985a The Huaca La Florida, Rimac Valley, Peru. In Early Ceremonial Architecture in the Andes, edited by Christopher B. Donnan, pp. 59-69. Dumbarton Oaks Research Library and Collection, Washington, D.C.

1985b Pachacamac, An Andean Oracle Under Inca Rule. In Recent Studies in Andean Prehistory and Protohistory, edited by D. Peter Kvietok and Daniel H. Sandweiss, pp. 133-149. Cornell Latin American Studies Program, Ithaca, New York.

Pauketat, Timothy R.

2007 Chiefdoms and Other Archaeological Delusions. Altamira Press, Lanham, Maryland.

Pozorski, Shelia, and Tom Pozorski

2003 La arquitectura residencial y la subsistencia de los habitantes del sitio de Moche: evidencia recuperada por el Proyecto Chan Chan - Valle de Moche. In Moche: hacia el final del milenio: Actas del Segundo Coloquio sobre la Cultura Moche: Trujillo, 1 a 7 de agosto de 1999, 1a edición, vol. I, edited by Santiago Uceda and Elías Mujica, pp. 119-150. Pontificia Universidad Católica del Perú, Lima, and Universidad Nacional de Trujillo, Peru.

Proulx, Donald A.

1973 Archaeological Investigations in the Nepeña Valley, Peru. Research Report No. 13. Department of Anthropology, University of Massachusetts, Amherst.

1985 An Analysis of the Early Cultural Sequence in the Nepeña Valley, Peru. Research Report Number 25. University of Massachusetts, Amherst.

Quilter, Jeffrey

1990 The Moche Revolt of the Objects. Latin American Antiquity 1:42-65.

1997 The Narrative Approach to Moche Iconography. Latin American Antiquity 8:113-133.

2002 Moche Politics, Religion, and Warfare. Journal of World Prehistory 16:145-195.

2008 Art and Moche Martial Arts. In The Art and Archaeology of the Moche, edited by Steve Bourget and Kimberly L. Jones, pp. 215-228. University of Texas Press, Austin. 2010 Moche: Media and Messages. Peabody Museum Press, Harvard University, Cambridge, Massachusetts.

Quilter, Jeffrey, and Luis Jaime Castillo Butters (editors)

2010 New Perspectives on Moche Political Organization. Dumbarton Oaks Research Library and Collections, Washington, D.C.

Quilter, Jeffrey, Régulo Franco J., César Galvez M., William Doonan, Catherine Gaither, Victor F. Vásquez Teresa E. Rosales T., Jaime Jiménez S., Hal Starratt, and Michele L. Koons

2012 The Well and the Huaca: Ceremony, Chronology, and Culture Change at Huaca Cao Viejo, Chicama Valley, Peru. Andean Past 10:101-131.

Ramírez, Susan E.

1995 De pescadores y agricultores: una historia local de la gente del Valle de Chicama antes de 1565. Bulletin de l'Institut Français d'Études Andines 24:245-279.

1996 The World Upside Down: Cross-Cultural Contact and Conflict in Sixteenth-Century Peru. Stanford University Press, Stanford, California.

2005 To Feed and be Fed: The Cosmological Bases of Authority and Identity in the Andes. Stanford University Press, Palo Alto, California. 
Rowe, John $\mathrm{H}$.

1954 Max Uhle, 1856-1944, A Memoir of the Father of Peruvian Archaeology. University of California Publications in American Archaeology and Ethnology (46) 1:1-134.

Russell, Glenn, and Bankes Leonard

1992 Informe preliminar: proyecto reconocimiento arqueológico del Chicama, resultados de la primera temporada de campo, 1989. Instituto Nacional de Cultura, Lima.

Schaedel, Richard P.

1951 Mochica Murals at Pañamarca. Archaeology 4(3): 145-154

1985 The Transition from Chiefdom to State in Northern Peru. In Development and Decline: The Evolution of Sociopolitical Organization, edited by Henri J. M. Claessen, Pieter van de Velde and M. Estellie Smith, pp. 156-269. Bergin and Garvey, South Hadley, Massachusetts.

Service, Elman R.

1962 Primitive Social Organization, An Evolutionary Perspective. Random House, New York.

1975 Origins of the State and Civilization: The Process of Cultural Evolution. Norton, New York.

Shimada, Izumi

1994 Pampa Grande and the Moche Culture. University of Texas Press, Austin.

2010 Moche Sociopolitical Organization: Rethinking the Data, Approaches, and Models. In New Perspectives on Moche Political Organization, edited by Jeffrey Quilter and Luis Jaime Castillo Butters, pp. 68-80. Dumbarton Oaks Research Library and Collection, Washington, D.C.

Smith, Adam. T.

2003 The Political Landscape: Constellations of Authority in Early Complex Polities. University of California Press, Berkeley.

Spencer, Charles S., and Elsa M. Redmond

2004 State Formation in Mesoamerica. Annual Review of Anthropology 33:173-199.

Stanish, Charles

2001 The Origin of State in South America. Annual Review in Anthropology 30:41-64.

Strong, William D., and Clifford Evans, Jr.

1952 Cultural Stratigraphy in the Virú Valley, Northern Peru: The Formative and Florescent Epochs. Columbia Studies in Archaeology and Anthropology Vol.4. Columbia University Press, New York.

Swenson, Edward R.

2006 Competitive Feasting, Religious Pluralism, and Decentralized Power in the Late Moche Period. In Andean Archaeology III: North and South, edited by William H. Isbell and Helaine Silverman, pp. 112-143. Springer/Plenum Press, New York.

2007 Adaptive Strategies or Ideological Innovations? Interpretive Sociopolitical Developments in the Jequetepeque Valley of Peru during the Late Moche Period. Journal of Anthropological Archaeology 26:253-82.

2011 Stagecraft and the Politics of Spectacle in Ancient Peru. Cambridge Archaeological Journal 21(2):285-315.

Topic Teresa L., and John Topic

1997a La guerra mochica. SIAN: Revista Aqueológica 4:10-12.

1997b Hacia una comprensión conceptual de la guerra andina. In Arqueología, antropología e historia en los Andes: homenaje a María Rostworowski, edited by Rafael Varón
Gabai and Javier Flores Espinoza, pp. 567-590. Instituto de Estudios Peruanos and Banco Central de Reserva del Perú, Lima.

Ubbelohde-Doering, Heinrich

1983 Vorspanische Gräber von Pacatnamú, Nordperu. Materialien zur Allgemeinen und Vergleichenden Archäologie Bd. 26. C.H. Beck, Munich.

Uceda Castillo, Santiago

1997 El poder y la muerte en la sociedad moche. In Investigaciones en la Huaca de la Luna 1995, edited by Santiago Uceda, Elías Mujica, and Ricardo Morales, pp. 177-188. Facultad de Ciencias Sociales, Universidad Nacional de La Libertad, Trujillo, Peru.

2001 Investigations at Huaca de la Luna, Moche Valley: An Example of Moche Religious Architecture. In Moche Art and Archaeology in Ancient Peru, edited by Joanne Pillsbury, pp. 47-67. National Gallery of Art., Washington, D.C.

2010 Theocracy and Secularism: Relationships Between the Temple and Urban Nucleus and Political Change at the Huacas de Moche. In New Perspectives on Moche Political Organization, edited by Jeffrey Quilter and Luis Jaime Castillo Butters, pp. 130-158. Dumbarton Oaks Research Library and Collection, Washington, D.C.

Uhle, Max

1913 Die Runinen von Moche. Journal de la Société des Americanistes de Paris 10:95-117.

1915 Las Ruinas de Moche.Boletín de la Sociedad Geográfica de Lima 30(3-4):57-71.

Verano, John

1998 Sacrificios humanos, desmembramientos y modificaciones culturales en restos osteológicos: Evidencias de las temporadas de investigación 1995-96 en Huaca de la Luna. In Investigaciones en la Huaca de la Luna 1995-1996, edited by Santiago Uceda, Elías Mujica, and Ricardo Morales, pp. 159-171. Facultad de Ciencias Sociales, Universidad Nacional de la Libertad, Trujillo, Peru.

2001 War and Death in the Moche World: Osteological Evidence and Visual discourse. In Moche Art and Archaeology in Ancient Peru, edited by Joanne Pillsbury, pp. 111-125. National Gallery of Art, Washington, D. C.

Willey, Gordon R

1953 Prehistoric Settlement Patterns in the Virú Valley, Peru. Smithsonian Institution, Bureau of American Ethnology, Bulletin 155. Washington, D.C.

1988 Portraits in American Archaeology: Remembrances of Some Distinguished Americanists. University of New Mexico Press, Albuquerque.

Wilson, David J.

1983 The Origins and Development of Complex Prehispanic Society in the lower Santa Valley, Peru: Implications for Theories of State Origins. Journal of Anthropological Archaeology 2:209-276.

1988 Pre-Hispanic Settlement Patterns in the Lower Santa valley, Peru: A Regional Perspective on the Origins and Development of Complex North Coast Society. Smithsonian Institution Press, Washington, D.C.

Yoffee, Norman

2005 Myths of the Archaic State: Evolution of the Earliest Cities, States and Civilizations. Cambridge University Press, New York. 


\section{Notes}

1. Too old for the military, William Duncan Strong regularly served as a consultant to the Navy (Willey 1988:91), and James Ford served in the U.S. Army Quartermaster Corps in Alaska (Willey 1988:62-63).

2. William Duncan Strong and Clifford Evans (1952:198-200) were the first to suggest that a man found in a high-status burial, termed the Warrior-Priest, had been a god impersonator.

3. Recently, an archaeological team under the direction of Steve Bourget (Atwood 2010) at the Huaca Úcupe uncovered a high-status burial with near-identical clothing and regalia as the Lord of Sipán. This led the discoverer to suggest that a Moche state indeed was extant on the North Coast with rulers following the same ritual program. Two (or more) similar burials do not directly inform us as to political systems but rather indicate that common ritual practices were carried out on the North Coast. In this case, it may suggest that the two centers of Sipán amd Úcupe were affiliated.

4. We infer that some huacas had short periods of use, given their small sizes, while others lasted for centuries with many remodeling phases, as we have observed in the field. In fact, this research question still remains to be investigated in detail.

5. We note that Thomas Patterson (1971) used the analogy of the spread of Christianity for explaining Chavín. Notably, early Christianity did not have a single unified doctrine. Rather, attempts at doctrinal unity-never fully achieved-only occurred after the religion was adopted as the state cult.

Submitted July 20, 2011; Accepted December 23, 2011; Revised January 6, 2012. 